\title{
Indigenous response to state colonisation in southern Chile
}

OSCAR TORO BARDECI

\begin{abstract}
The invasion of indigenous territories by national states in the $19^{\text {th }}$ century produced a forced social and physical re-accommodation of Pehuenche groups, inhabitants of the southern Andes. In a context of cultural homogenisation policies and justifying the territorial appropriation, the $19^{\text {th }}$ century written sources shaped a stereotyped image of Pehuenche. In this paper, beyond the stereotypes, historical and ethnographic information are compared, and how Pehuenche responded to and shaped changes are recognised.
\end{abstract}

Keywords: Indigenous cultural persistence. Material culture. Pehuenche groups. State colonialism. Post-colonial perspective.

\section{Resposta indígena à colonização do estado no sul do Chile}

\section{$\overline{\text { Oscar TORo BardecI }}$}

Governmental Chilean Scholar (from Becas Chile) for 2017 - 2021 period. PhD candidate in Archaeology at University College London (UCL). Archaeologist and master in History at University of Chile. E-mail: oscar.toro.17@ucl. ac.uk/osctoro@gmail.com
Resumo: A invasão dos territórios indígenas pelos Estados nacionais no século XIX produziu uma realocação social e física forçada de grupos Pehuenche, habitantes do sul dos Andes. Em um contexto de políticas de homogeneização cultural e justificação da apropriação territorial, as fontes escritas do século XIX moldaram uma imagem estereotipada dos Pehuenche. Neste artigo, vai-se além dos estereótipos, comparando informações históricas e etnográficas e reconhecendo como os Pehuenche responderam e se moldaram às mudanças.

Palavras-chave: Persistência cultural indígena. Cultura material. Grupos Pehuenche. Colonialismo estatal. Perspectiva pós-colonial.

RECEBIDO: $16 / 02 / 2020$

APROVADO: 07/03/2020 


\section{Introduction}

The Pehuenche are indigenous people of Andean South America who became incorporated into the Nation States of Chile and Argentina. Until the $19^{\text {th }}$ century Pehuenche Territory was beyond a Spanish-indigenous border that had emerge along the Biobío River. They practiced transhumance between the high valleys of the Andes, to the west, and Pampas, to the east, becoming commercial intermediaries for goods and resources moving between indigenous and Spanish settlements. Additionally, Zavala Cepeda (2012) proposes that Pehuenche groups of the $18^{\text {th }}$ century could be considered as "Andean Mapuche", representing the communities which caused the spreading of Mapuche culture to the east and north from their lowlands in western valleys and Pacific coast (territory known as Araucanía) (Figure 1). Mapuche and Pehuenche groups share cultural aspects such as language, kinship system, clothes and rituals.

Figure 1: Map of southern cone of South America, depicting main geographic places referred and the relative extension of indigenous territories before mid-19 $9^{\text {th }}$ century

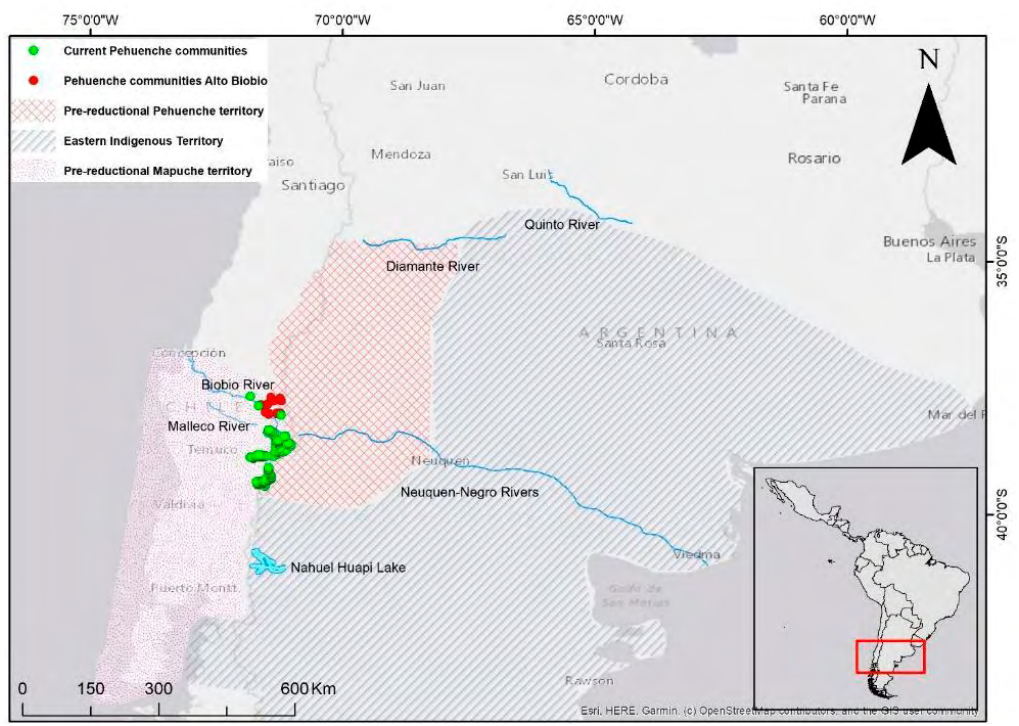

Source: own elaboration. 
However, between 1862 and 1884 the Indigenous Territory was invaded by the nation-states of Chile and Argentina. Within a relatively few years, the indigenous groups were forced to reduce their territories (called "reducciones") and the settled communities we currently know were created, through the promulgation of legislation which did not consider the Pehuenche prior socio-political organisation. The communities and indigenous reductions of southern Chile were constituted between 1884 and 1929 (BENGOA, 1992; MILLALÉN et al., 2006).

This social dismembering is a continuous process of changing cultural traditions of Pehuenche groups, reflected in the significant reduction of their ancient mobility between Andean mountainous and Pampas.

How did the Pehuenche groups respond to their incorporation to the Chilean state from the second half of the $19^{\text {th }}$ century? The central idea of this paper is to show how certain cultural characteristics persisted in the Pehuenche lifestyle combined with adopted aspects since their incorporation to the nation-states in the $19^{\text {th }}$ century. I interpret this synthesis as a capacity of persistence and recognition of cultural diversity within the wider-colonialist society.

Chilean and Argentinian expansionist policies from mid-19 ${ }^{\text {th }}$ century started with "official emissaries" sent to the Indigenous Territory to collect various type of information about the resources in these lands and the behaviour of their people. Among these were Scientists, travellers, missionaries and militaries (MILLALÉN et al., 2006). I contrasted the writing documents that some of these state emissaries left to ethnographic observations. I focused on information regarding the state policies that affected to the mountainous-transhumant groups and the description of changes and continuities in their material culture.

Most of the examined historical sources, stereotyped indigenous peoples as barbarians, that are incapable of self-ruling, to have a peaceful existence or any type of advancement without external assistance. Under this view, their material culture would have little role to play (HINGLEY, 2014). I believe, on the contrary, that the study of changes and continuities in a multi-ethnic context must be evaluated in the daily practices of domestic life. Within 
such practices, material culture can play an active role in the emergence of social identities (LIGHTFOOT; MARTINEZ; SCHIFF, 2010).

State policies caused the economic impoverishment of Pehuenche communities, through the loss of territories and its resources, particularly the loss of most of their pastures lands -which resulted in severe decline in their livestock. Additionally, the poor productive conditions of the lands assigned by the state caused that Pehuenche -along with the rest of the southern indigenous groups- to become part of the lowest socio-economic segment of Chilean society. However, the Pehuenche culture and identity is still distinguishable through their language, political organisation, ritual acts and the small-scale seasonal mobility maintained in some communities.

This cultural persistence is still visible despite the intended cultural homogenisation sustained by Chilean state and justified by the historiography of the $19^{\text {th }}$ and $20^{\text {th }}$ centuries. For instance, the Bordering Studies School ("Estudios Fronterizos") in the 1980s lead by Sergio Villalobos was the main expression of the acculturative perspective. They propose a process of miscegenation and passive cultural incorporation of the indigenous populations to the colonialist culture, through regular commercial contacts in the Biobío frontier, concluding in the 1880s (ADÁN, 2014).

\section{The expansion of nation-states and the pehuenche in the $19^{\text {th }}$ century}

In the period after Chilean Independence in 1810 but before the military invasion to their territories, starting in the 1860s, reports describe the Pehuenche as pastoralist groups who practiced transhumance within the Andean valleys. According to information from a German explorer in the 1830s, the main difference between the Pehuenche and the Mapuche was their mobile condition: "Pehuenche are nomads and will never become accustomed to living in just one place, differentiating for this, among other aspects, from the Araucanians [Mapuche]" (POEPPIG, 1960, p. 391). ${ }^{1}$

1 The original reads: "Los pehuenches son nómades, y jamás se acostumbrarán a tener un domicilio fijo, diferenciándose ya a este respecto en muchos rasgos de los araucanos". 
The same source describes their motivations to move: "They move constantly through the Andes, either for an innate inclination to an itinerant life or forced by necessity, occasionally presented as pastoralists, they do not know other wealth than their herds" (POEPPIG, 1960, p. 391). ${ }^{2}$

The Pehuenche practiced their transhumance within the Andean hills and valleys, mainly, with territories belonging to specific kinship groups.

Only when winter covers all the mountain summits with thick snow, mainly in the colder months of July and August, and when the infinite rains and indescribable river rises made impossible the mobile way of life, do they build a little more protected house, to spend the winter in. When the snow melts again, they go up to elevated points of the mountain, although within a given district, which belongs to their families since immemorial times (POEPPIG, 1960, p. 392). ${ }^{3}$

For the $19^{\text {th }}$ century, there are more detailed description of Pehuenche settlements. The major of Concepción in southern Chile, who travelled from this town to Buenos Aires to inform national policies on roads that connect both sides of the Andes, passed through the mountains of the Araucanía observing that Pehuenche built their settlements using natural resources such as wood from the forest and animals' hide. The following quotation describes the interior of the conical tents in which they lived:

According with the number of women that are inside are the number of divisions, demarcated with just the hide of a horse or with a bar disposed over two wooden supports. Their mattresses are two or three woollen hides; their

2 The original reads: 'Vagan permanentemente por los Andes, ya sea por una inclinación innata a la vida errante, o bien obligados a ello por la necesidad, y se presentan en ocasiones como pastores, que no conocen otra riqueza que sus rebaños'. 3 The original reads: "Sólo cuando el invierno cubre todas las partes superiores de las montañas con profundas nieves, sobre todo en los meses fríos de julio y agosto, y cuando los interminables aguaceros y las indescriptibles crecidas de los ríos hacen imposible la vida vagabunda, construyen una vivienda un poco más protegida, para invernar en ella. Cuando se vuelve a derretir la nieve, suben a puntos cada vez más elevados de la montaña, pero sin salirse de un determinado distrito, que ha pertenecido desde tiempos inmemoriales a su tribu". 
clothes are ponchos of guanaco, skunk, fox, hare or vizcacha, and from every single part of these emerge horse's fat everywhere, and an unbearable fetidness. The fire is always burning inside, the meat is thrown over the skins used for seating or for their bed or for the horses, and all around is dirty and untidy (DE LA CRUZ, 1835 [1806], p. 37). ${ }^{4}$

The building techniques and resources employed are noted in the following description made by the same author:

Their habitations are made of horse's hide, tied between each other with ropes made of the sinews extracted from the horses. They are structured in two rooms, but each one is composed of six or eight [divisions?]. To build them, indigenous women put wooden supports from the smaller to the larger to facilitate the runoff of water, some bars or colihue canes crossed, and over this assemble they put the sheets of hide, which form a tent, but with the distinction that an open breach is left at the top from where the smoke exits. Through this open space enters the cold and water (DE LA CRUZ, 1835 [1806], p. 37). ${ }^{5}$

The significant data provided by these explorers is accompanied by pejorative adjectives, such as: "unbearable fetidness" and the "dirtiness" of Pehuenche houses, and the lack of a fixed place to

4 The original reads: "Segun las mugeres que hay adentro, son las divisiones, pero son deslindadas con solo la piel de un caballo, ó por medio de una varilla, puesta sobre dos horquillas. Sus colchones son dos ó tres pieles de ganado lanar; sus cubiertas lloycas de guanaco, chinques, zorros, marros, vizcachas, y cada cosa de esta brota grasa de caballo por todas partes y una fetidez insufrible. El fuego lo mantienen de continuo adentro; la carne tirada sobre los pellejos ó pieles que usan para sentarse, ó para su cama, ó para el caballo, y en fin aquello todo es una mugre y un desaseo". 5 The original reads: "Sus habitaciones son de pieles de caballo, cocidas unas con otras por medio de las cuerdas que de los nervios de los caballos sacan. Son en dos paños, y cada uno se compone de seis ú ocho. Para armarlos ponen las indias unos horconcillos, clavados á sus fuerzas de menos á mayor; para que tengan descenso las aguas sobre la horqueta de los horcones, algunas varillas ó cañas de coliu atravesadas; y sobre este armamento, tienden por una parte y otra el paño de pieles, que forman una carpa: pero con la distincion que estos quedan abiertos en la cumbrera para que salga el humo, por cuyo abertor, que es de una cuarta de ancho, entra el yelo y el agua". 
live ("vida errante" in Spanish), which all indicate a strong ethnocentric perspective that discriminated against the Pehuenche. The use of these adjectives justified the territorial dispossession of these groups, arguing that they do not own or work a specific piece of land, hence do not produce in economic terms (lack of agriculture) and the poor life conditions in which they lived.

Additionally, the frequency of the mobility depended on the quantity of land owned/accessed by each family. Their tents were grouped with three, six or eight together (which conform camps known as "tolderías", Figure 2), conformed by extensive families, which commonly positioned their mobile houses around the lonko's ${ }^{6}$ (literally "head", acting as a chief) and his family. These settlements were located on river or estuary shores where their animals could drink and pasture. Once the pasture was exhausted, they moved to another place. Families who owned more lands spent less time at each location (DE LA CRUZ, 1835 [1806]).

The numerous tent camps represent several Pehuenche leaders in the past. This changed with the forced reduction of indigenous population to the current settled communities, because in the post-reductional period the lonko figure broadened its representation to the community, exceeding the extended families living in the "tolderías". Today's lonkos have more territory to control, but less power to exercise. However, this continuity of traditional lonko leadership does not have legal recognition from the state, which now have the legal figure of the president of the community and its committee.

6 They were commonly designated as "cacique" in the written records since the Colonial times ( $16^{\text {th }}$ century onwards), a term which is believed has a Caribbean origin. For this paper I will use the conceptualisation from Mapuche-Pehuenche political system. 


\section{Figure 2: Illustration of a Pehuenche settlement or "toldería" from 1840}

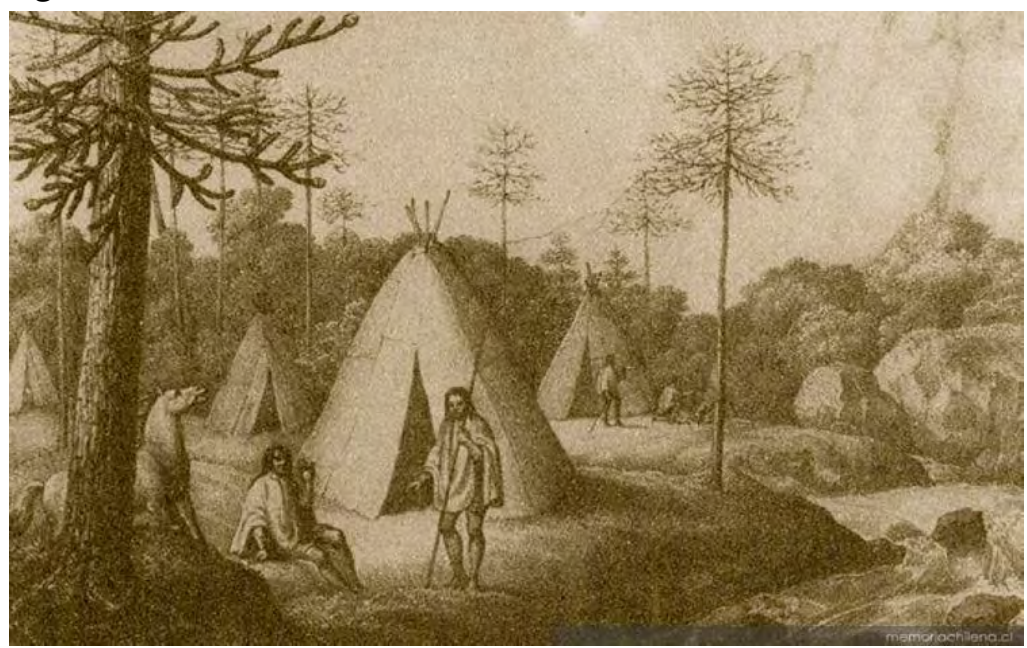

Source: Poeppig (1960).

It was during the $19^{\text {th }}$ century that a major expansion in territorial control by the nation-states of Chile and Argentina occurred, accompanied by the physical exploitation of indigenous people with the stated intention to homogenise and subsume their identities within a national identity. The following paragraph clearly reflects the colonialist and homogenising thinking in 1845 , when the nation-states were in a process of territorial expansion into Indigenous Territory:

They slowly adapt to governmental laws and authority, little by little they change their clothes, men are beginning to use trousers and hats and women wear blouses, transforming into civilised Chileans. In this way indian people in northern Chile were, without any doubt, domesticated and saved from the extinction, to the point that, currently, even among the common people are washing away the indigenous features and it is forming a new nation which adds millions of new parishioners to the Church (DOMEYKO, 2010 [1845], p. 191). ${ }^{7}$

7 The original reads: "Lentamente se habitúan a las leyes y a la autoridad del gobierno, poco a poco cambian su indumentaria, los hombres empiezan a vestir pantalones y sombreros, las mujeres visten camisetas, y se transforman en 
In the above quotation is explicit the topic of the inclusion of indigenous people in the Chilean nation and Christian Church, this is to be achieved by denying their indigenous condition, which would conduct them to the "extinction". This project of assimilation claimed succeeded in northern Chile, where indigenous people were culturally and physically assimilated as a "civilised nation" as reflected in the adoption of certain types of clothes and their participation in Catholic rituals.

This is an example of a worldwide colonial discourse taking shape during this period. The West defined itself as the "civilised" against the "otherness" of the colonised subject. This idea gave Western people a sense of pertinence and superiority, mainly in contrast to the "others", seen as subjects in need of control, education, moral and material progress. All this reflected in the written documents of nineteenth-century explorers on colonised territories (HINGLEY, 2014). Moreover, "the oppositions created between self and other were highly judgemental of Indigenous ways of life, effectively providing a context for the appropriation of land, resources, and possessions by the colonizing power" (HINGLEY, 2014, p. 8).

The starting point of the physical invasion into Indigenous Territory by the Chilean state was 1862, when it was proposed to move the former Biobío border further south to the Malleco River, action promoted by Cornelio Saavedra. This was materialised through a line of forts that were located to facilitate Chilean control over these incorporated territories (MILLALÉN et al., 2006).

In a similar action, in 1878 the Argentinian government enacted law No947, which brought the border with the indigenous populations of the Pampas and Patagonia south from the Quinto and Diamante rivers to the line formed by Negro and Neuquén rivers. To that date, the War Secretary, Julio Roca (the ideologue of the military invasion of Indigenous Territory and future President), had in mind the expansion to the Andes, clearly expressed in his

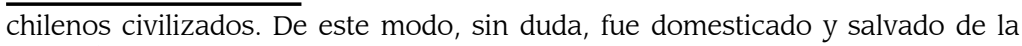
extinción, el pueblo indio en todo el norte de Chile, hasta el extremo de que, actualmente, hasta entre la plebe se están borrando los rasgos indígenas y se está formando una nación nueva que aporta a la Iglesia millones de nuevos adeptos". 
own words: "I know that among them there are braves and spirited leaders preparing their spears preferring to die rather than giving up their life of pillaging. We will go there to seek them even if they hide in the deepest valleys of the Andes" (CURRUHUINCA; ROUX, 1993, p. 144). ${ }^{8}$

Despite law No947, in 1879, under the command of Napoleón Uriburu, the Argentinian troops planned to extend beyond the Negro-Neuquén River, and as a response the Pehuenche of northern Neuquén grouped under the futa lonko ("big head" or "big leader") Purrán, to resist invasion. A year later, in 1880, Purrán, was trapped on the western side of the Andes, when he was caught by an Argentinian detachment lead by Manuel Ruybal, who had the promised the futa lonko the following:

\begin{abstract}
About the benefit which would receive from the Government, when every indigenous were presented they would be given land and agriculture tools, food, livestock, etc. Once subjugated to civilisation, living among the Christians, their conditions will improve considerably and they will have the same rights as Argentinians (PECHMANN, 1980 [1878], p. 37).9
\end{abstract}

Between 1881 and 1883 there were two further military campaigns. The first one directed at the Nahuel area, far beyond the border established by the 1878 law. The Argentinian army advanced until the shores of the Nahuel Huapi lake, and along with the advance of the Argentinians, the indigenous groups were running away, producing a few clashes. In these, 45 indigenous people were killed, 150 imprisoned, and the Argentinians confiscated 6500 sheep, 1700 cattle and 2300 horses (CURRUHUINCA; ROUX, 1993). These figures indicate the importance and scale of animal resources among the indigenous groups at the time.

8 The original reads: "Sé que entre ellos hay caudillos valientes y animosos que aprestan sus lanzas prefiriendo sucumbir antes que renunciar a la vida de pillaje. Allí iremos a buscarlos aunque se oculten en los valles más profundos de los Andes". 9 The original reads: "[...] Acerca de los beneficios que recibirían del Gobierno, cuando todos se hubieran presentado, que se les daría tierra y útiles de agricultura, racionamiento, ganado, etc., que una vez sometidos a la civilización, en vida con los cristianos, mejorarían considerablemente sus condiciones, y tendrían todos los derechos de los argentinos". 
This underlines two central aspects with respect to the indigenous people. First, the promises of a better life through the access to technological tools and resources were conditioned on their subjugation to national state rules which would bring "civilisation" to them. Second, the promises of a better conditions of life was also dependent on the acceptance of creole colonists ("colonos") being settled among them, on their lands. Regretfully -although expectable-, none of the promises were fulfilled, as I will show below.

In 1881, the Chileans felt the need to respond to successive campaigns by the Argentinian army against indigenous groups on the eastern side of the Andes that crossed the national frontier marked by the Andean mountains. The response to this was to build a series of Chilean military installations, or forts, along the trans-Andean border pass. This was a material expression of the process of incorporating the previously indigenous territories into the Chilean state (MILLALÉN et al., 2006).

In the middle of the military operations in Biobío River area in 1883, Martin Droully, who was in charge of the expeditions to the mountainous valleys of the Andean area, made explicit the objectives of this campaign: "the instructions that I have received were: try to subjugate the indians to one or another authority of their own choice; but induce them to abandon the mountain valleys where they are in misery, having to steal to avoid starving" (GUEVARA, 1902, p. 470-471). ${ }^{10}$

The intention was for the indigenous groups to abandon their transhumant movement across the Andes, something that was no longer practicable within the new political order of national boundaries. The intention was to create a "deserted" image of the mountain valleys, in terms of resources and population.

The view of indigenous lands as "lands of cultural incompetence and impotence" (cf. WOBST, 2005) is another way of colonialist imposition, under the idea that the absence of material indicators of economic production were equated to a "savage" state. This logic is still claimed as a justification for dispossessing indigenous people from their lands until the present-day (BENGOA, 2004).

10 The original reads: "Las instrucciones que tengo son: tratar de someter a los indios a una u otra autoridad, a elección de ellos; pero inducirlos a que abandonen los valles de cordillera donde están en la miseria, teniendo forzosamente que robar para no morirse de hambre". 
As a result of these nation-state movements, between 1884 and 1929, large portions of indigenous lands were confiscated and then publicly auctioned, in exchange for "Mercedes de Tierra" (land grants) assigned as small portion of lands designated by the Chilean state. This implied significant losses in material and cultural terms, where the landscape was important in the definition of an indigenous identity, as was their livestock and farming to their subsistence (BENGOA, 1992; MILLALÉN et al., 2006). At this point, indigenous people of southern Chile participated in the transformation of previous territorial units ${ }^{11}$ by relocating to "reducciones", which implied the disintegration of their former socio-political organisation, being physically and socially marginalised by the state.

The scenario was more complicated because near the location of the new indigenous "reducciones" were settlements of Chilean/ Hispanic colonisers whose arrival had been facilitated by the construction of the national forts within former Pehuenche Territory. This furthered the economic impoverishment on the indigenous groups and their social and cultural expressions (contrary to the promises made to Purrán a few years before...). One case in Pehuenche territory is the "San Ignacio de Pemehue" Hacienda, which was founded in 1863 in the former territories of the lonko Naguel, from whom the state seized his lands, and passed them to several colonialist owners (including Cornelio Saavedra, named above as the organiser of the earlier Chilean invasion to Indigenous Territory). This was the cause of continuous struggles over the disputed lands. Another case, around 1870, is the appropriation of piece of lands in Queuco valley from an individual named Juan Núñez Fernández, lands that were later named Fundo Queuco, which remains in dispute to the present (BENGOA, 2004).

11 The basic territorial units in the Mapuche world are: A) Lof: socio-political space under a lonko guidance, where conflicts are discussed, and other topics are defined. Is formed by patrilineal extensive families and could be assimilated to the current communities. B) Rewe: socio-political and territorial aggrupation of several lof. C) Ayllarewe: socio-political aggrupation of several rewe where political and military decisions were made. D) Futan Mapu: territorial aggrupation of several ayllarewe which share geographical characteristics. One of the Futan Mapu in Colonial times was the Pehuenche, including groups from both side of the Andes (MILLALÉN et al., 2006). 
These examples show how the dynamics of colonialist occupation and displacement of indigenous groups unfolded. One of the consequences of these dynamics was the breaking of territorial and cultural continuity of Pehuenche groups. In terms of their economy, they were given patches of land less suitable for their way of life, i.e. narrow spaces next to gorges where the soil is less productive in agricultural terms, and without taking into account the mobile condition of the Pehuenche, resulting in the loss of most "veranadas" (high-lands where they take their animals for grazing during the summer season).

Moreover, the lack of perspective of the spatial continuum in the indigenous logic implies a misrepresentation of their culture. Under this biased view, lies a justification for colonialist behaviours seen in the representation of indigenous history and culture as poorer and less complete than Western society's (WOBST, 2005).

\section{Contemporaneous case study ${ }^{12}$}

The current Pehuenche communities are circumscribed in the high section of Biobío River, specifically in Alto Biobío, Lonquimay, Icalma-Galletué and Curarrehue regions, in Andean Araucanía, along with some communities on the Argentinian side (Figure 1). All these territories include stands of Araucaria trees (Araucaria araucana) in higher points of the mountains (between 1000 and $2000 \mathrm{~m}$ a.s.l.) which produce a specie of pinenuts collected since pre-Hispanic times. From here the Pehuenche were given their ethnonym (Pehuen: Araucaria forest; che: people).

There are two turning points in the recent history of Pehuenche people. The first was the process of the forced reduction of the territory at the end of the $19^{\text {th }}$ century detailed in the previous section.

12 This section includes some data from the in-progress ethnoarchaeological research as part of author's Doctoral work (2017-2021). For this reason, I do not give too much details about location and characteristics of the community which I am working with. I have been given oral consent from the participants of the ongoing work and the clearance from the Ethic Committee at Institute of Archaeology, UCL (Reference number 2017-18: 055), to develop this investigation. 
The other process was the re-localisation of entire communities to new areas in Alto Biobío, due to the building of hydro-electric plants, at the end of the $20^{\text {th }}$ and beginning of $21^{\text {st }}$ centuries (MORAGA, 2001). The latter has had a significant effect on traditional lifestyles, i.e. by incorporating them to the social and economic spheres of Chilean society under a capitalist system, mainly through shorth-term paid work outside the communities.

Despite the external factors that strongly influenced their traditions, these communities maintain a strong identity and aspects of their traditional lifestyle in relation to that of wider Chilean society. One of these aspects is the use of their language chedungun (literally, the speaking of the people), that they did not lose despite the introduction of the Spanish since the $18^{\text {th }}$ century.

Another adaptation to socio-political changing scenarios is that some families divide their annual residence between permanent settlements ("invernadas") in the lower valleys, from March to December (Figure 3), and seasonal settlements in "veranadas" (December to March) in the upper valleys between January and February, where they take their livestock to pastures and collect pinenuts from Araucaria trees (Figure 4). The numbers of animals that contemporary familial unit own is significatively inferior to those recorded for the pre-reductional period, with flocks formed by dozens of animals overall (e.g. GONZÁLEZ, 1980). They also maintain propitiation rituals within their respective communal territories, the nguillatun ceremony (FOERSTER, 1980; FUENZALIDA, 2010; GONZÁLEZ, 1980; GUNDERMANN, 1981; ISLA, 2001).

\section{Figure 3: View of Pehuenche's permanent settlements on lowlands, Alto Biobío}

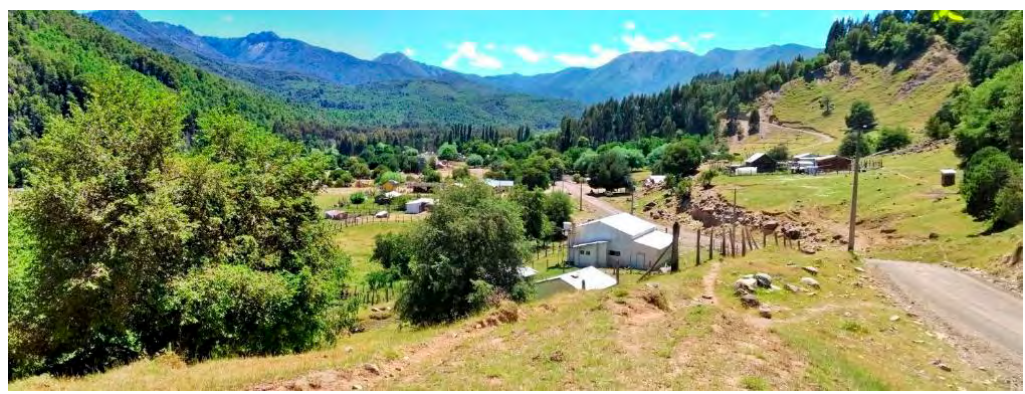

Source: Photo by the author (December 2018). 
I have begun to conduct ethnographic work with the Pehuenche. In their permanent settlements, with several nuclear families -related through their patrilineal side- I have encountered ongoing changes, e.g. the "casas-subsidio" (subsidised modern houses given to poor families through a public fund subsidy) greenhouses, technological devices (e.g. televisions, computers, game consoles) and electricity that support longer-term occupation.

Specifically, the "casas-subsidio" have affected the spatial distribution within the permanent settlements in recent years. This is because these houses include some spaces that the traditional layout of Mapuche-Pehuenche houses had previously kept separated.

For instance, traditionally, the cooking area is a separate building, but with this new type of houses the kitchen comes incorporated within the rest of the house. I observed two different situations related to the presence of subsidised houses. In one case, members of the household kept using their traditional kitchen-house, with its respective hearth placed at the centre around which almost all social and familiar daily activities take place. In the other case, the family unit did not use the kitchen-house regularly, just for social purposes (e.g. birthday parties) and for cooking special foods in the fireplace (e.g. pinenuts). The later correspond to a family which has better economic situation in comparison to the former case, which could be a factor that influences whether they adopt, or not, these types of changes, considering the expenses associated with the use of electricity and gas. These cases also serve to illustrate how change and continuity are expressed within the same Pehuenche community.

The conceptualisation of permanent settlement among the Pehuenche is relatively new, as this form of dwelling emerged just after their territorial reduction at the end of the $19^{\text {th }}$ century. Before that, the historic literature mentioned above reports that their settlements were seasonal as they moved their encampments several times per year. The main difference between pre and post-reductional period is the way in which they use the space and the building materials used for the erection of their settlements. In the past, Pehuenche families dwelled in tents made of animal's hide, grouping several families near the lonko of these extensive families. This 
pattern was independent from the ecological environment which was being used, in the lower or higher valleys, although in the colder months they built a "more protected" house (POEPPIG, 1960, p. 392).

Currently, there is still a seasonal occupation of different spaces, but they differentiated from those described in that the hides used for tents were replaced by wooden houses, and that the occupation of the lands in the high valleys are no longer extensive kin groups but individual houses of nuclear families, constituting a space and time of dispersion from the rest of the community.

\section{Figure 4: View of Pehuenche's seasonal settlement environment on highlands, Alto Biobío}

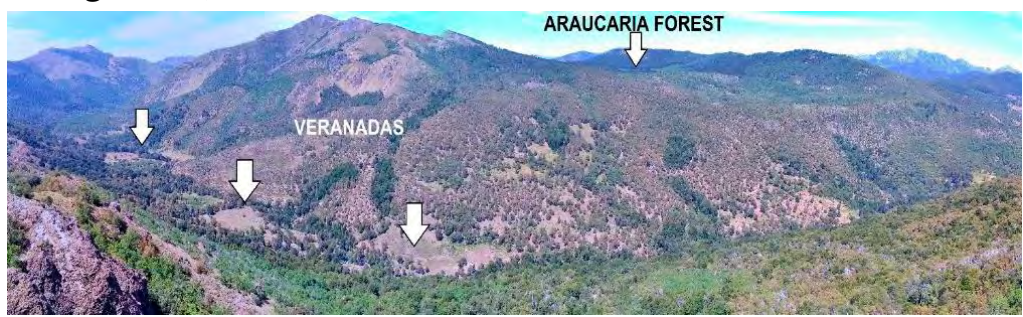

Source: Photo and modifications by the author (January 2019)

Interestingly, the description made by Guevara (1913) and Coña (MOESBACH; COÑA, 1930) for the beginnings of the $20^{\text {th }}$ century referred to Mapuche people, coincides with a description of an indigenous permanent settlement in current Alto Biobío. They observed that some of the structures were made of wood. The roofs were made either of corrugated iron or tile, or some of them thatched. The plans consisted in several interior rooms, positioning as many fireplaces as women lived in the structure. In addition, there were other structures surrounding the main house, such as the kitchen, the barn and another habitational house for visitors. Moreover, there was a pen for the livestock and an orchard (Figure 5). This description could imply that current Pehuenche adopted the house forms and settlement organisation of neighbouring Mapuche within their permanent settlements. This change from pre-reductional times (cf. POEPPIG, 1960) shows how Pehuenche adapted their mobility and settlement pattern in response to colonial policies. 
Figure 5: Contemporary example of permanent settlement location in a mountainous environment and the presence of several structures conforming the "invernada", Alto Biobio

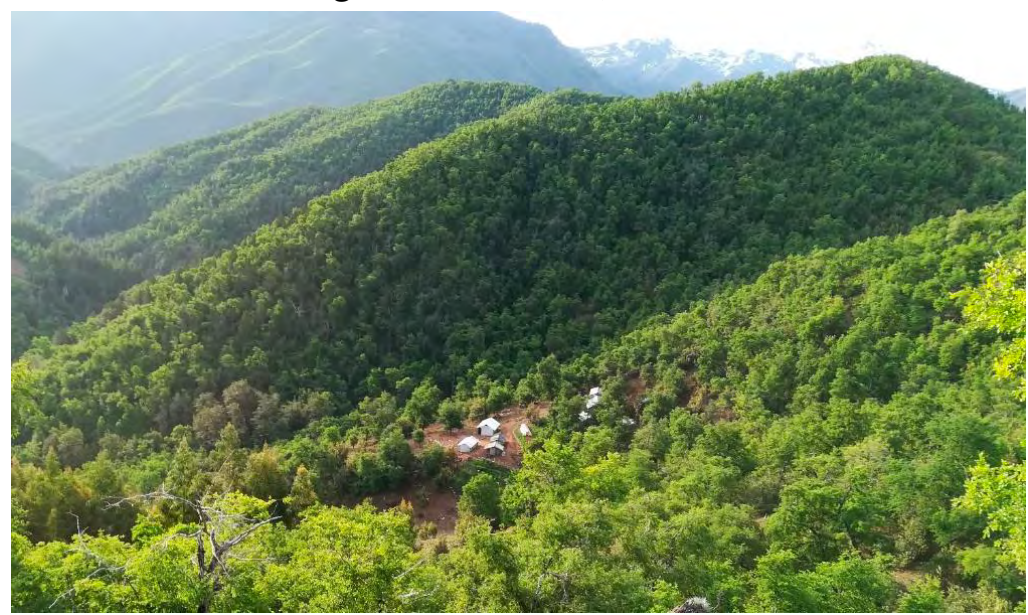

Source: Photo by the author (November 2019)

In present-day Pehuenche settlements domestic arrangements include tables, wicker chairs, wooden bench, dishware and bowls, cups and bottles, knives and spoons, and metallic pans. This description coincides with Guevara's (1913), who in the $20^{\text {th }}$ century describes the material culture associated with households as elements of "Chilean style", noting a change from previous Mapuche and Pehuenche, who before mid-19 $9^{\text {th }}$ century did not know tables and they sat on sheep hides, placing the plates directly over the floor. Inside the settlements from this period reports describe objects made of silver, mainly related to horses' equipment, such as stirrups and spurs (MOESBACH; CONA, 1930; THOMPSON, 1863), which are also familiar in the current Pehuenche settlements.

\section{Discussion}

I have identified several factors that conditioned some behaviours of the past and currents Pehuenche communities of Alto Biobío, which have their origins after the national-state incorporation of 
these indigenous groups. These factors altered "traditional" activities (e.g. seasonal movements between lowlands and highlands) and originated new types of communal/familial dynamics.

Firstly, the territorial struggles have strong influence in the mobility cycle of these communities. This is mainly due to the occupation of territories that remain under dispute: settlement of entire families in these "bordering" places have to reclaim and/ or defend them against private Chilean "colonos" or neighbour communities.

The social reconstruction of territorial organisations implies the need to re-negotiate relationships both within and outside the community, sometimes re-calling old tensions of processes that originated at the end of $19^{\text {th }}$ century or even before in the case of intra-ethnic struggles. These are represented by the flow of indigenous populations caused by the Chilean-Argentinian invasion to these territories. These movements intervened in the composition of the territorial units, due to the process of adaptation of the foreign families to the receiving community (MILLALÉN et al., 2006).

In this sense, is important to bear in mind that "contact situations are often significant watersheds in reshaping cultural orders since they provide individuals from all walks of life with new opportunities to negotiate and redefine their social identities in the process of daily practice" (LIGHTFOOT; MARTINEZ; SCHIFF, 2010, p. 157).

Secondly, the key role of missionaries among the Pehuenche throughout the Colonial and Republican periods serves to exemplify how some colonial institutions later facilitated the incorporation of the indigenous groups to the nation-state from the $19^{\text {th }}$ century. They had already incorporated external influences on their religious lives when the state definitively invaded their territories by that time.

However, the mixture of faiths expresses intricately, which confused nineteenth-century explorers. For instance, in mid$19^{\text {th }}$ century the Chilean authorities have a concern because they noticed a division between the quotidian indigenous life and the cultural values transmitted through the school education. What 
was learned in school was rapidly forgotten in parent's home, where they lived as "savages", obscuring the educational and evangelical labour. According to Domeyko (2010 [1845]), some indigenous visited the church, but they did not learn about the Christian doctrine.

Putting this in the indigenous perspective, they would say that the school and church influenced their cultural values, with the intention of subsuming their culture into national Chilean norms. I believe that the behaviour described by Domeyko was their way to respond to external influences and changes throughout the last centuries choosing what to accept, reject, resist or adapt.

Nowadays, the calendar of Catholic festivals is important to some Pehuenche families, many of whom continue a mixture of traditional indigenous and Christian beliefs, which implies their participation in the rituals and ceremonies from both origins. In addition, it is important to highlight the more recent participation in Evangelical church practices. This usually means that evangelical converts cannot take part in either Catholic or indigenous rituals and has prevented their participation in the movement to highland pastures and collection of pinenuts, or in any of the considered "indigenous traditional" activities.

Thirdly, the role of the school within the communities is altering the way of transmission of cultural values and worldview of Pehuenche by passing curricula contents to the young generations, more related to the wider society's reality than the community's. Another alteration that the presence of school is causing relates to the term dates for obligatory state education. This determines the return times from the highlands at the end of the summer (classes in schools start officially no later than the first days of March). I was told that this was different as recently as 20 years ago. Schools used to wait for the kids to came back from the summer campsites to start the school season, which depended on weather and collection of pinenuts conditions, sometimes delaying the starting of classes until April-May.

School is also a factor for the emigration to near cities of the younger members of the communities, because they aspire to a better education (technical-professional) to have better job 
opportunities in the future, not necessarily intending to return to their communities of origin, at least in the short or medium term.

Fourthly, although we can no longer speak about a nation-state colonialism in the same form that it took in the past, indigenous groups are still marginalised from the dominant society, because of an economic system that maintained inequalities through an unequal access to capital. In this sense, "we cannot argue that Empire is over; it continues in new form that are subject to continuous transformation and obfuscation" (HINGLEY, 2014, p. 14).

Current examples of this fourth aspect are monthly social security payment and temporal paid work. The former corresponds to a payment assignation to poor families by the Chilean state, which immediately incorporated them within the capitalist economy that rules the political order in Chile, although under a paternalistic logic, which avoid the individual and, in this case, collective development of better economic conditions.

Moreover, I observed that paid employment has prevented families who would normally have gone to the "veranadas" from continuing to do so. Instead of taking the animals to the highland pastures in the summer, the adult members of the families find waged temporary work (e.g. collecting fruits for big farming companies) during this season. This factor could be affecting just one or two members of each nuclear family but influences its mobility as a unit.

Finally, these situations are commonly known among presentday indigenous communities thanks to their cultural memory. They passed the knowledge on how their ancestors survived colonialism, and this experience becomes a part of their identity and traditions. History and archaeology could help to rescue these memories and avoid maintaining a colonialist context of such identities (HANDSMAN; RICHMOND, 2010).

However, is clear that the exploratory and scientific expeditions served as a basis for the military occupation of former Indigenous Territory in the $19^{\text {th }}$ century, and subsequent state appropriation of these lands. They perpetuated the stereotyped image of the indigenous groups as opposite to the "civilised", which would be the coloniser society. 


\section{Conclusions}

As part of the analysis of written and ethnographic sources, one of the main manifestations of the cultural persistence of Pehuenche groups in the context of the state colonisation, occur at a settlement level, specifically in the spatial use of the land and the social dynamics that surround this space. Although they were forced to reduce their territories and consequently diminish the territorial extension of their mobility, along with their principal source of wealth (herds), they re-adapted these mobility patterns to the new colonial situation, now living in the "reducciones".

Pehuenche families adopted new technologies, especially between the $20^{\text {th }}$ and $21^{\text {st }}$ centuries (e.g. "Chilean style" domestic elements, electric energy), although the space dedicated to family reunion and social life still happens in the surroundings of a fireplace inside their kitchens. This "traditional" behaviour could respond to a precarious economic condition of most families of indigenous communities in Alto Biobío. Nevertheless, it acts as an agent for the preservation and transmission of Pehuenche cultural values (e.g. through the speaking of chedungun), despite the presence of alienating factors such as school and paid work.

Changes in the leadership structure of Alto Biobío groups imposed by the state, altered but did not cause the disappearance of traditional authorities (lonkos). This alternative socio-political dynamic that intertwin state-imposed institutions and practices with the maintenance of cultural expressions from pre-Chilean colonisation reflects the capacity of these former bordering groups to adapt and respond to external changes. Materially, this is expressed in the current form of dwelling, now in permanent settlements and in the construction of more durable houses, using wood instead of hide.

All these situations reflect an ongoing process of adoption and re-accommodation of cultural behaviours which blurred the line between the "traditional" and the "incorporated", in which the colonial legacy is playing a double role of denying and producing culture, at the same time. In this sense, colonised indigenous people should be considered as active subjects who responded to changes with particular social dynamics and material expressions. 
Pehuenche people neither disappeared nor were pacifically incorporated to the dominant society as some have argued. Instead, cultural changes and continuities permanently reinforced their own culture and project its future in the context of a colonialist state that still neglects the cultural diversity and plurality of identities to whom inhabit its territory.

\section{References}

ADÁN, L. Los Reche-mapuche a través de su sistema de asentamiento (s. XV-XVII). [s.l.]: Universidad de Chile, 2014.

BENGOA, J. Quinquén: 100 años de historia Pehuenche. Santiago: LOM Ediciones, 1992.

Los pehuenches de la cordillera. In: BENGOA CABELLO, J. (org.). La memoria olvidada: Historia de los pueblos indígenas de Chile. Santiago: Publicaciones del Bicentenario, 2004. p. 479 - 503.

CURRUHUINCA, C.; ROUX, L. Las matanzas del Neuquén: Crónicas mapuches. Buenos Aires: Editorial Plus Ultra, 1993.

DE LA CRUZ, L. Descripción de la naturaleza de los terrenos que se comprenden en los Andes, poseídos por los Peguenches y los demás espacios hasta el río de Chadileubu. Buenos Aires: Imprenta del Estado, 1835.

DOMEYKO, I. Araucanía y sus habitantes. Santiago: Biblioteca Fundamentos de la Construcción de Chile, 2010.

FOERSTER, R. Estructura y funciones del parentesco Mapuche: su pasado y presente. [s.l.]: Universidad de Chile, 1980.

FUENZALIDA, D. Aproximaciones a la significación espacial de los Pewenche relocalizados en Ayin Mapu. [s.l.]: Universidad de Chile, 2010. GONZÁLEZ, H. Un siglo en la economía de una reducción Mapuche cordillerana. [s.l.]: Universidad de Chile, 1980.

GUEVARA, T. Las últimas familias i costumbres araucanas. Santiago: Imprenta Barcelona, 1913.

Ocupación de Villarrica i del alto Biobío. In: Historia de la civilización de Araucanía. Santiago: Imprenta Barcelona, 1902. p. 461 - 480. GUNDERMANN, H. Analisis estructural de los ritos Mapuches Nguillatún y Pîntevún. [s.l.]: Universidad de Chile, 1981. 
HANDSMAN, R. G.; RICHMOND, T. L. Confronting Colonialism: The Mahican and Schaghticoke Peoples and Us. In: MROZOWSKI, S.; PREUCEL, R. (orgs.). Contemporary Archaeology in Theory. 2. ed. Chichester: Wiley-Blackwell, 2010. p. 349 - 363.

HINGLEY, R. Colonial and Post-colonial Archaeologies. In: GARDNER, A.; LAKE, M.; SOMMER, U. (orgs.). The Oxford Handbook of Archaeological Theory. Oxford: Oxford University Press, 2014. Available at: <http:// oxfordhandbooks.com/view/10.1093/oxfordhb/9780199567942.001.0001/ oxfordhb-9780199567942-e-008>. Access on: jun. 1, 2020.

ISLA, J. Pewenche: Estudios sobre territorio y proceso social. [s.l.]: Universidad de Chile, 2001.

LIGHTFOOT, K. G.; MARTINEZ, A.; SCHIFF, A. M. Daily Practice and Material Culture in Pluralistic Social Settings: An Archaeological Study of Culture Change and Persistence from Fort Ross, California. In: MROZOWSKI, S.; PREUCEL, R. (orgs.). Contemporary Archaeology in Theory. 2. ed. Chichester: Wiley-Blackwell, 2010. p. $156-174$.

MILLALÉN, J. et al. i...Escucha, winka...! Cuatro ensayos de historia nacional Mapuche y un epílogo sobre el futuro. Santiago: LOM Ediciones, 2006.

MOESBACH, E. W.; COÑA, P. Vida y costumbres de los indígenas araucanos en la segunda mitad del siglo XIX. Santiago: Imprenta Cervantes, 1930.

MORAGA, J. Aguas Turbias: La central hidroeléctrica Ralco en el Alto Bío Bío. Santiago: Observatorio Latinoamericano de Conflictos Ambientales, 2001.

PECHMANN, G. A orillas del Biobío. In: El Campamento 1878 : Algunos cuentos históricos de fronteras y campañas. 2. ed. Buenos Aires: Editorial Universitaria de Buenos Aires, 1980. p. 32 - 44.

POEPPIG, E. Un testigo en la alborada de Chile (1 826-1829). Santiago de Chile: Zig-Zag, 1960. Available at: <http://www.memoriachilena. cl/602/w3-article-8392.html>. Access on: jun. 1, 2020.

THOMPSON, M. Informe comisión exploradora del río Biobío i sus afluentes. Anales de la Universidad de Chile, [s. 1.], v. XXIII, n. 2, p. 129-238, 1863.

WOBST, M. Power to the (indigenous) past and present! Or: The theory and method behind archaeological theory and method. In: SMITH, C.; WOBST, M. (orgs.). Indigenous Archaeologies: Decolonizong theory and practice. London; New York: Routledge, 2005. p. 17 - 32.

ZAVALA CEPEDA, J. M. La presencia mapuche en los Andes según las fuentes coloniales chilenas. Revista de Estudios Trasandinos, [s. l.], v. 17, n. 1, p. $119-134,2012$. 